Janusz Krysztofik

Instytut Zarządzania Wiedza w Krakowie

Anna Piestrzyńska

Akademia Ignatianum w Krakowie

Anna Walulik

Akademia Ignatianum w Krakowie

\title{
Strukturalna analiza biblijnych tekstów narracyjnych - implikacje pedagogiczne
}

Zainteresowanie narracjami $w$ naukach społecznych wiąże się $z$ podjęciem badań opartych na paradygmatach innych niż pozytywistyczny'. Chociaż samo pojęcie narracji jest różnie rozumiane przez nauki humanistyczne i różnie interpretowane przez przedstawicieli poszczególnych dyscyplin naukowych, to jednak za myślenie narracyjne można uznać takie, które pokazuje, że rzeczywistość nie jest odzwierciedlana, lecz konstruowana i interpretowana przez jednostkę ${ }^{2}$. To stanowisko konstruktywizmu jawi się jako wspólne dla większości badaczy narracji, bez względu na reprezentowana przez nich dyscyplinę naukową. Refleksja nad narracjami wymaga uważnego i twórczego namysłu, co rodzi potrzebę poszukiwania coraz to nowych sposobów tworzenia wiedzy, która wspomagałaby człowieka $w$ rozwiązywaniu jego indywidualnych i społecznych problemów.

\footnotetext{
${ }^{1}$ Zob. szerzej: A. Walulik, Moderacyjne i synergiczne kształtowanie dorosłości. Propozycja typologii modeli znaczeń wiedzy religijnej na przykładzie Korespondencyjnego Kursu Biblijnego, Wyższa Szkoła Filozoficzno-Pedagogiczna „Ignatianum”, Wydawnictwo WAM, Kraków 2011.

${ }^{2}$ D. Klus-Stańska, Narracje w szkole, [w:] Narracja jako sposób rozumienia świata, red. J. Trzebiński, Gdańskie Wydawnictwo Psychologiczne, Gdańsk 2002, s. 190-191.
} 
Praktyka badawcza ${ }^{1}$ pokazuje, że taką rolę może spełniać analiza strukturalna tekstów narracyjnych ${ }^{2}$.

\section{Narracja jako interpretacja rzeczywistości}

Narracja porządkuje wiedzę osoby o świecie, o ludziach i o zachodzących między nimi relacjach ${ }^{3}$. Oznacza to, że historie, poprzez które człowiek poszukuje rozumienia rzeczywistości, nie istnieją jako coś obiektywnego. Jednostka interpretuje zdarzenia jako określone historie za pomocą procedur zawartych w schemacie narracyjnym, który modeluje bohaterów narracji, ich wartości, intencje oraz wynikające z ich realizacji plany, komplikacje oraz uwarunkowania i szanse ich przezwyciężania. Interpretacje historii mogą również dokonywać się bez udziału specyficznych schematów narracyjnych, czego następstwem jest rozumienie konstruowane na podstawie ogólniejszych struktur wiedzy. Narracyjna interpretacja rzeczywistości pozwala na uwzględnianie kontekstu i ułatwia wykorzystywanie doświadczenia jednostki $w$ procesie rozumienia siebie i innych oraz faktów społecznych. Powstaje $w$ ten sposób wiedza narracyjna związana z doświadczeniem jednostkowym, która posiada charakter subiektywny i podmiotowy ${ }^{4}$. Trzebiński uważa, że wszystko to, co „jednostka realnie widzi, słyszy, myśli i jak przeżywa kolejne sytuacje i zdarzenia, jest współkształtowane przez treść rozwijającej się narracji" ${ }^{5}$. Narracje pokazują rzeczywistość rozumianą przez opowiadającego dane doświadczenie i wyrażają pozycję autora wobec

\footnotetext{
1 Próby zastosowania poszczególnych kategorii $w$ odniesieniu do różnych problemów podejmowaliśmy już wcześniej. Efekty prowadzonych analiz prezentowaliśmy podczas konferencji z cyklu „Biografia i badanie biografii” organizowanych w Łodzi.

2 Analizę strukturalną tekstów narracyjnych w odniesieniu do tekstów biblijnych polskiemu czytelnikowi prezentują: Roman Murawski i Zbigniew Marek. Jest to propozycja pracy z narracyjnymi tekstami biblijnymi, która ma prowadzić do odkrywania zbawczego orędzia poprzez refleksję nad elementami typowymi dla dzieła literackiego, takimi jak: miejsce, czas, aktorzy, wartości i oczekiwania. Jej praktyczne zastosowanie Zbigniew Marek poznał podczas warsztatów prowadzonych przez Gabriellę Miller. Zob. R. Murawski, Katecheza w formie analizy tekstu, [w:] Katechizacja różnymi metodami, red. M. Majewski, Inspektorat Towarzystwa Salezjańskiego, Kraków 1994; Kurs Biblijny, z. 2, red. Z. Marek, Wydawnictwo WAM, Kraków 1993; Z. Marek, O korzystaniu z Pisma Świętego w głoszeniu zbawczego orędzia, „Horyzonty Wiary” 1995, R. 6, nr 3, s. 53-55; Z. Marek, Biblia w katechetycznej posłudze słowa, Wydawnictwo WAM, Kraków 1998; J. Kochel, Z. Marek, Pedagogia biblijna w katechezie, Wydawnictwo WAM, Kraków 2012.

J. Trzebiński, Narracyjne konstruowanie rzeczywistości, [w:] Narracja jako sposób rozumienia świata..., dz. cyt., s. 19.

${ }^{4}$ M. Straś-Romanowska, Psychologiczne badania narracyjne jako badania jakościowe $i$ ich antropologiczne zaplecze, [w:] Narracja - teoria i praktyka, red. B. Janusz, K. Gdowska, B. de Barbaro, Wydawnictwo Uniwersytetu Jagiellońskiego, Kraków 2008, s. 61.

${ }^{5}$ J. Trzebiński, art. cyt., s. 27.
} 
przedmiotu, interpretując opisywane zjawiska $w$ indywidualny sposób. Ujawniają sens i unikalny system znaczeń autora, co pozwala na refleksję. Oznacza to, że ludzkie myślenie, postrzeganie, wyobrażenia i wybory przebiegają według struktur narracyjnych. Opowieść staje się swoistym „medium” między przeżyciem czasowym a aktem narracji ${ }^{1}$ oraz narzędziem rozumienia przez osoby siebie jako aktorów życia społecznego. Służą one do rozumienia zewnętrznych zdarzeń i roli, jaką $w$ nich odgrywają 2 .

Doświadczanie wydarzeń może dokonywać się z perspektywy uczestnika bądź obserwatora. Przekształcane jest $w$ refleksyjne myślenie na temat tych wydarzeń poprzez zastanawianie się nad „całą historią”, „próbą jej zrozumienia”, „nadaniem jej głębszego sensu”, „wyciąganiem wniosków”. Zachodzi wówczas przejście z pozycji bezpośredniego uczestnika do pozycji obserwatora poszukującego sensu w otaczających go zdarzeniach ${ }^{3}$. Postrzeganie z pozycji uczestnika zwykle (choć nie zawsze) posiada charakter celowego działania. Należy mieć przy tym na uwadze i to, że za refleksją stoją systemy wiedzy. W dużej mierze są one uformowane pod wpływem oddziaływań społecznych i stanowią indywidualny zapis wiedzy kulturowej o danym zjawisku. Oznacza to, że treść refleksji nad historią różni się od treści historii bezpośrednio doświadczanej oraz że w umyśle aktywizowane są inne systemy wiedzy niż te, które kształtowały doświadczanie tego zdarzenia. Na treść refleksji ma też wpływ aktualny stan emocjonalny człowieka i cel jej podjęcia.

\section{Analiza strukturalna narracji}

W pracy nad tekstami biblijnymi analiza strukturalna tekstów narracyjnych uznawana jest za metodę, która umożliwia wyodrębnienie w tekście aktorów, miejsc, czasu, wartości i oczekiwań. Ma ona prowadzić do odkrywania zbawczego orędzia poprzez refleksję nad elementami typowymi dla dzieła literackiego, takimi jak: miejsce, czas, aktorzy, wartości i oczekiwania. Wszystkie te elementy ujawniały się bardzo wyraźnie podczas wielokrotnego odczytywania narracji, co skłoniło do zaaplikowania tego sposobu postępowania do tekstu o charakterze biografii.

\footnotetext{
${ }^{1}$ W ten sposób Denis Villepelet na Kongresie Europejskiej Ekipy Katechetycznej w maju 2010 roku interpretował pojęcie narracyjności u P. Ricouera.

${ }^{2}$ K. J. Gergen, M. M Gergen, Narrative and the Self as Relationship, [w:] Advances in Experimental Social Psychology, t. 21, red. L. Berkowitz, Academic Press, London 1988, s. 17-56.

${ }^{3}$ J. Trzebiński, art. cyt., s. 27.
} 
W konsekwencji dokonana została próba możliwie szerokiego określenia cech poszczególnych elementów, których wskazanie i interpretacja może służyć już nie w odkrywaniu zbawczego orędzia, lecz w rozumieniu każdego doświadczenia. Proponowany $w$ analizie strukturalnej sposób postępowania przeprowadzony na materiale biograficznym pokazał, że analizę strukturalną tekstów narracyjnych należy uznać nie tyle za metodę, co bardziej za technikę badawczą. W takim rozumieniu została przedstawiona charakterystyka poszczególnych elementów wyodrębnianych w tekście.

Aktorzy, których wyróżniamy $w$ toku prowadzonej analizy, to zarówno osoby, jak i rzeczy, przedmioty pełniące $w$ narracji jakąś rolę. Wskazuje się nie tylko na ludzi, ale także inne podmioty, którym przypisuje się działanie. W tekstach biblijnych jest często mowa o Bogu i jego wysłańcach, ale też mocach nieosobowych takich jak: moce ciemności, moce demoniczne, wiatr, czy burza ${ }^{1}$. W odniesieniu do tekstów biograficznych pomocne może okazać się wskazanie osób fizycznych uczestniczących w wydarzeniu oraz innych, które mają wpływ na interpretację zdarzenia. Dobrze jest również rozróżnić osoby planu głównego i osoby mniej istotne dla przebiegu wydarzenia, a także osoby prawne, instytucje, urzędy, organizacje itd. oraz podmioty abstrakcyjne (z lub bez antropomorfizacji). Analiza strukturalna tekstów narracyjnych nie ogranicza się jednak do wymienienia poszczególnych aktorów. Szczególnie istotne jest zidentyfikowanie relacji między wskazanymi aktorami. W ich interpretacji wykorzystuje się zasady wypracowane przez personalizm, co umożliwia podkreślanie autonomicznej wartości osoby oraz zakłada wspieranie jej rozwoju na drodze nabywania umiejętności podporządkowania wartości ekonomicznych i technicznych wartościom osobowoduchowym ${ }^{2}$.

Personalizm wyraża otwarcie na egzystencję człowieka ujmowaną w wymiarze przestrzenno-czasowym, wyraźnie eksponując porzucenie statycznej koncepcji osoby poprzez poszukiwanie aktywnych uwarunkowań życia człowieka, zanurzonych $w$ egzystencję ${ }^{3}$. Przyjęcie zasad personalizmu $w$ procesie analizy relacji pomiędzy aktorami dotyczy zarówno tekstów biblijnych jak i innych narracji, ze względu na istnienie dwóch podstawowych jego typów: antropocentrycznego

\footnotetext{
1 J. Kochel, Z. Marek, dz. cyt., s. 296-297.

2 M. Nowak, Pedagogika personalistyczna, [w:] Pedagogika: podręcznik akademicki, t. 1, red. Z. Kwieciński, B. Śliwerski, Wydawnictwo Naukowe PWN, Warszawa 2003, s. 237.

${ }^{3}$ Tamże, s. 232.
} 
i teocentrycznego. Odróżnia je odmienne objaśnianie natury człowieka i jego ostatecznego celu. Personalizm antropocentryczny uznaje człowieka, a personalizm teocentryczny Boga za ostateczne centrum odniesień. Personalizm teocentryczny określa naturę człowieka mianem „bytu pochodnego”, co oznacza, że człowiek całe swe istnienie zawdzięcza Bogu jako Bytowi nieskończonemu i pozostaje $w$ istotnej od Niego zależności ${ }^{1}$.

W odniesieniu do analizy strukturalnej rozróżnienie to jest szczególnie ważne, bo uświadamia istnienie różnego rodzaju tekstów narracyjnych oraz konieczność opowiedzenia się przez badacza za określoną koncepcją człowieka. Badacz, wyodrębniając z narracji aktorów i ustalając zachodzące pomiędzy nimi relacje, dokonuje charakterystyki zarówno jednych jak i drugich. Ważne jest wskazanie fragmentów narracji, które skłaniają badacza do ich interpretacji. W procesie tym szczególnie cenne może okazać się graficzne przedstawienie dostrzeżonych związków pomiędzy aktorami (zob. ryc. 1).

Rycina 1. Przykład graficznego przedstawienia wybranych elementów analizy strukturalnej ${ }^{2}$

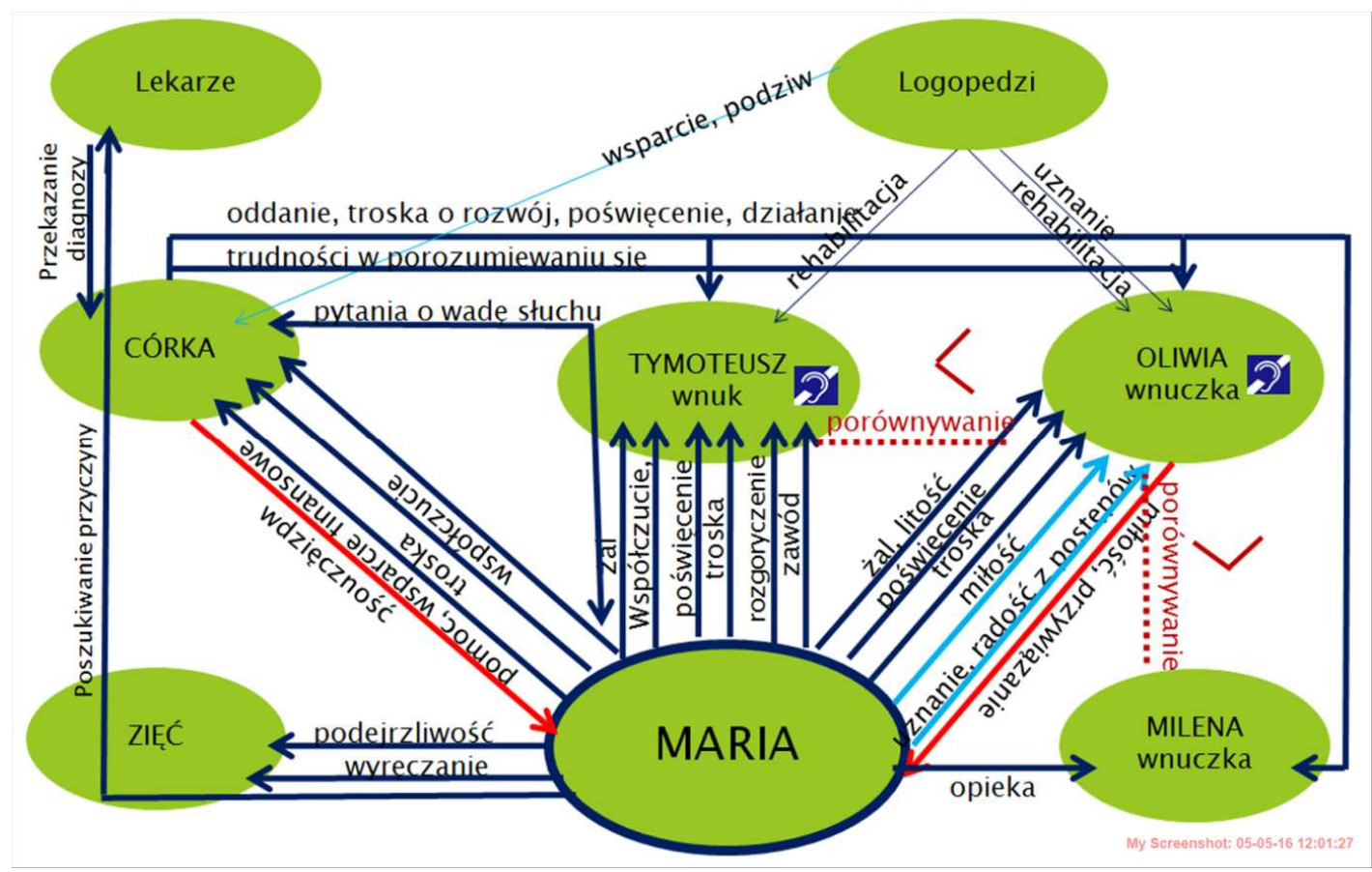

\footnotetext{
R. Niparko, Wychowanie religijne jako wychowanie humanistyczne - perspektywa personalistyczna, „Paedagogia Christiana” 2003 nr 2 (12), s. 19.

Schemat został przygotowany przez Annę Piestrzyńską w procesie prowadzenia badań nad doświadczeniami dziadków niesłyszących wnuków. Autorką narracji jest Maria babcia dwojga niesłyszących wnuków.
} 
Kolejną kategorią identyfikowaną $w$ narracji przy pomocy analizy strukturalnej stanowi miejsce. Maria Mendel przyjmuje, że „miejsce to tam, gdzie toczy się nasze życie, to tam, gdzie jesteśmy, z uwzględnieniem wszystkich ontologicznych aspektów znaczenia bycia. Jeżeli 'świat' rozumieć jako bliżej nieokreśloną, przeczuwaną jedynie, niedotkniętą przestrzeń, 'nasz świat' będzie miejscami pamiętającymi naszą obecność. Noszącymi jej ślady, znaczącymi to, co o nich myślimy, mówimy, snując życiowe narracje, żyjąc własne życia”¹. Leszek Koczanowicz jest przekonany, że „wprowadzenie kategorii 'miejsce' w centrum dyskursu pedagogicznego zmienia znacząco cały ten dyskurs, otwiera go na nowe możliwości interpretacyjne i ujawnia związki, które $w$ innym przypadku pozostałyby ukryte" ${ }^{2}$. Przy czym - jak zauważa Jarosław Jagieła - jest to kategoria „zaniedbana” $w$ dyskursie pedagogicznym³ ${ }^{3}$.

W określaniu miejsca z wykorzystaniem analizy strukturalnej tekstów narracyjnych przyjmuje się szerokie rozumienie tego pojęcia, co upoważnia do dokonywania identyfikacji geograficznej (np. kontynent, kraj, województwo, miasto, miejscowość, dzielnica, ulica itp.), czy instytucjonalnej (np. dom, szkoła, miejsce wykonywania pracy zawodowej, urząd itp.), albo emocjonalnej (np. podwórko, łąka, droga itp). Można wskazywać wszystko, gdzie autorzy narracji umiejscawiają swoje doświadczenia. Ważne jest, by odkryć ich znaczenie dla aktorów zdarzenia i dynamiki rozumienia doświadczenia. Ten sposób prowadzenia badań wymaga, by posługiwać się określeniami narratora, gdyż dla interpretacji wskazanych miejsc nie jest obojętne, czy autor wspominając dzieciństwo mówi o tym, że wychodziło się na dwór, na pole, czy na podwórko. Frank Ankersmit uznaje, że wszelkie doświadczenie (także doświadczenie historyczne) jest nieodwołalnie kontekstualne 4 . Ewa Kurantowicz zaś zauważa, że w badaniach nad uczeniem się dorosłych coraz częściej jest ono postrzegane jako proces o charakterze społecznym, kontekstowym, a nie tylko indywidualnym, psychologicznym ${ }^{5}$.

\footnotetext{
1 M. Mendel, Kategoria miejsca $w$ pedagogice, [w:] Pedagogika miejsca, red. M. Mendel, Wydawnictwo Naukowe DSWE TWP, Wrocław 2006, s. 22.

${ }_{3}^{2}$ Pedagogika miejsca, dz. cyt., okładka.

3 J. Jagieła, Czas i przestrzeń transakcji szkolnych, [w:] Analiza transakcyjna $w$ edukacji, red. J. Jagieła, Wydawnictwo im. Stanisława Podobińskiego Akademii im. Jana Długosza, Częstochowa 2011, s. 50-51.

4 F. Ankersmit, Narracja, reprezentacja, doświadczenie. Studia z teorii historiografii, Universitas, Kraków 2004, s. 213.

${ }^{5}$ E. Kurantowicz, Badanie lokalnych kontekstów uczenia się. Wybrane (andragogiczne) uzasadnienia i spory, „Teraźniejszość - Człowiek - Edukacja” 2006 nr 2(34), s. 63-64.
} 
Dlatego należy przyjąć, że miejsca wyodrębnione $w$ procesie analizy strukturalnej ze względu na ich subiektywny i kontekstowy charakter posiadają wymiar proksemiczny. Pozwala to nie tylko dostrzegać wzajemne przestrzenne relacje między aktorami, ale także związki między osobami i otoczeniem materialnym z uwzględnieniem różnych kultur i innych kontekstów doświadczenia.

Kolejną kategorią umożliwiającą analizę narracji jest czas. Grecy używali dwóch słów odpowiadających nowożytnemu słowu czas - chronos i kairos, które posiadają nieco inne znaczenia. Chronos odnosi się do czasu, którego rozciągłość można zmierzyć i umieścić na osi czasu, podając jego długość. Jest trwającym okresem, w którym pojawia się możliwość zrobienia, pojawienia się czegoś, a także możliwość przedłużenia, gdy jest to konieczne. Stąd urządzenia do mierzenia czasu nazywa się „chronometrami”. Kairos posiada nieco inny sens. Określenie to odnosi się również do pewnego okresu, ale akcent położony jest nie na mierze, lecz na tym, co się wydarza $w$ „mierzonym” okresie. Tak rozumiany czas jest bardziej sposobnością do zdobycia, osiągnięcia, ukazania się czegoś niż rozciągłością. Jest czasem wydarzenia, to znaczy odpowiednią porą na coś1. Te dwa różniące się od siebie $w$ języku greckim pojęcia czasu pozwalają lepiej zobaczyć to, co się $w$ rzeczywistości odnosi do przeżywania i doświadczania czasu. Wskazywanie tej kategorii $w$ analizie narracyjnej służy zrozumieniu sposobu działania $w$ historii wymienionych aktorów. Dlatego $w$ procesie analizy strukturalnej można mieć na uwadze czas: liczony obiektywnie, np. kalendarzowy (rok, miesiąc, dzień), czy zegarowy (np. pory dnia lub nocy); czas zakresowy określany subiektywnie (np. w latach, w okresie studiów, po zawarciu małżeństwa, po ukończeniu szkoły, $w$ trakcie choroby); czas sytuacyjny (np. w trakcie wykonywanej pracy, będąc za granicą itd.). To rozróżnienie oparte jest na fenomenologicznych ujęciach czasu, w których czas subiektywny jest „doznawany”, a obiektywny „postrzegany”. Co więcej czas ludzkiego doświadczenia uznaje się za bardziej pierwotny od potocznego czasu świata i rozumiany jako czas źródłowy: czas życia, przeżyć, pamięci, oczekiwania, wyobraźni i świadomości².

Opowiadanie o codzienności zwykle zawiera informacje o wartościach, jakie autor przypisuje poszczególnym osobom, czy wydarzeniom oraz kierowanych

\footnotetext{
${ }^{1}$ W. Zatorski, Kairos i Chronos $w$ życiu lidera, http://ps-po.pl//wp-content/uploads/2013/08/kairos_i_chronos_w_zyciu_lidera.pdf.

${ }^{2}$ A. Ziółkowska, Czas, tożsamość i podmiotowość. Wokół wybranych ujęć fenomenologicznych i hermeneutycznych, [w:] Aporie czasu, red. P. Orlik, Wydawnictwo Naukowe Instytutu Filozofii UAM, Poznań 2011, s. 167-198.
} 
względem nich oczekiwaniach. Rola wartości polega na przenikaniu, poruszaniu i kształtowaniu ludzkiej świadomości oraz wywoływaniu przeżyć i pobudzaniu do działania, a przyjęta hierarchia wartości wytycza cele, kierunki działania oraz scala ich wytwory'. Podstawę dokonywanych przez osobę identyfikacji stanowi poznanie, które ukazuje wartość $w$ pozytywnym albo negatywnym świetle. Wynika z tego, że wartości wpływają na kształt nadawany zarówno życiu poszczególnych osób jak i większych społeczności. Dlatego w kolejnych etapach posługiwania się analizą strukturalną zmierza się do odtworzenia i uporządkowania występującego w opowiadaniu świata wartości, które są różne dla poszczególnych aktorów lub sytuacji.

Świat wartości odnosi się do norm, sądów i ocen moralnych ${ }^{2}$, dlatego analiza strukturalna wymaga, aby ustalić i wskazać wartości odnoszące się do poszczególnych aktorów. W narracjach biograficznych zwykle wskazać można prezentowane przez aktorów wartości etyczne i moralne, ale także wartości pragmatyczne (przydatne - nieprzydatne); wartości utylitarne (bez wartości, tanie, drogie, bezcenne); wartości estetyczne (brzydkie - ładne); wartości emocjonalne i uczuciowe (straszne - obojętne - wzruszające); wartości egzystencjalne (bezsensowne - sensowne, pesymistyczne - optymistyczne) oraz wartości symboliczne. Stanowią one nie tylko kryterium oceny rozstrzygania o tym, czy coś jest wartościowe lub niewartościowe, ale stają się samym dobrem identyfikowanym z przedmiotem oceny ${ }^{3}$.

Przy porządkowaniu świata wartości można posługiwać się wcześniej sporządzonym schematem relacji zachodzących między aktorami, co $w$ interpretacji pozwala określić stosunek poszczególnych osób do dobra i zła, zajmowane pozycje, wyrażane przekonania, a także to, $w$ jakiej relacji pozostają do zamierzeń narratora. Działania te odgrywają znaczącą rolę $w$ podejmowanych próbach zrozumienia doświadczenia, gdyż zarówno narrator jak i badacz opowiadają się za konkretnymi wartościami czy wzorcami.

Identyfikacja aktorów, miejsca, czasu i wartości ułatwia ustalenie wzajemnych oczekiwań i życzeń poszczególnych aktorów opowiadania. Są one bliskie określaniu wartości, ale nie jednoznaczne. O ile wartości wyrażają

\footnotetext{
${ }^{1}$ L. Dyczewski, Miejsce i funkcja wartości w kulturze, „Keryks” 2008, nr 7, s. 58-61.

2 Z. Marek, Podstawy wychowania moralnego, Wyższa Szkoła Filozoficzno-Pedagogiczna "Ignatianum", Wydawnictwo WAM, Kraków 2005, s. 34-35.

${ }^{\prime \prime}$ M. tobocki, Wychowanie moralne w zarysie, Oficyna Wydawnicza „Impuls”, Kraków 2002, s. 72.
} 
subiektywne odniesienie człowieka do otaczającej go rzeczywistości, ale $w$ kontekście ustalonych, powszechnie uznanych zasad, to przy wydobywaniu z tekstu oczekiwań i życzeń zwracamy uwagę na odniesienia w wymiarze osobistym.

W rozumieniu analizy strukturalnej tekstów narracyjnych oczekiwania można odnieść do dwóch słownikowych znaczeń: „spodziewanie się czegoś od kogoś, spodziewanie się po kimś jakiegoś zachowania" oraz oczekiwania jako „nadzieja człowieka, który liczy na pewne powodzenie, opierając się na posiadanych przez siebie obiektywnych przesłankach"1. Przy czym należy zauważyć, że oczekiwania wskazywane $w$ procesie analizy strukturalnej „obiektywizują” się przez sam fakt odnoszenia ich do innych osób. Mimo że pojęcie „życzenie” uznawane jest za bliskoznaczne $w$ odniesieniu do pojęcia „oczekiwanie”, to wyodrębnienie tej kategorii pozwala poszerzyć rozumienie interpretowanej rzeczywistości. Można je również rozpatrywać $w$ dwóch znaczeniach: jako pragnienie, chęć posiadania czegoś oraz „pragnienie, aby coś się ziściło”². Oznacza to, że analiza strukturalna pozwala wskazać oczekiwania aktorów względem sytuacji, względem siebie, innych osób, instytucji i organizacji, a także oczekiwań zracjonalizowanych, uzasadnionych wydarzeniem i sytuacją lub doświadczeniem życiowym oraz całej sfery życzeń i nadziei formułowanych i kierowanych do siebie oraz innych. Określenie oczekiwań i życzeń pozwala badaczowi odkrywać to, co narratorzy uznają za prawdopodobne, możliwe, godne uwagi, konieczne, przypadkowe, a także to, jakie posiadają cele, motywy czy intencje swego działania i wreszcie jakie pojawiają się rozczarowania, zaskoczenia, pytania.

Analogicznie jak w przypadku określania wartości, można oczekiwania i życzenia analizować wykorzystując graficzną ilustrację relacji pomiędzy innymi elementami. Wskazywanie poszczególnych kategorii za pomocą analizy strukturalnej służy przygotowaniu możliwie różnorodnej przestrzeni interpretacji z pozornie przeciwstawnych perspektyw: wewnętrznej i zewnętrznej, obiektywnej i subiektywnej, badanego i badacza. Przy czym to, co zewnętrzne i obiektywne jako podlegające interpretacji narratora i/lub badacza służy uzyskiwaniu wiedzy o charakterze podmiotowym i subiektywnym. Zastosowanie analizy strukturalnej

\footnotetext{
1 Praktyczny słownik współczesnej polszczyzny, t. 25, red. H. Zgółkowa, Wydawnictwo Kurpisz, Poznań 2000, s. 210.

2 Praktyczny słownik współczesnej polszczyzny, t. 50, red. H. Zgółkowa, Wydawnictwo Kurpisz, Poznań 2000, s. 322.
} 
w badaniach zmierzających do odkrywania rozumienia doświadczeń wpisuje się $w$ biograficzną refleksję nad uczeniem się dorosłych ${ }^{1}$.

Zaproponowany sposób analizy narracji odwołuje się do rozumienia procesu wychowania „w ujęciu drogi edukacyjnej”². Olga Czerniawska postrzega go jako „zjawisko przenikania wzajemnego, wpływów środowiska społecznego, które tworzy natura i kultura, a także środowisko niewidzialne jednostki, na które składa się jej bieg życia: czas historyczny, wydarzenia osobiste i globalne, przeżycia, wspomnienia, zapamiętane krajobrazy; przedmioty, zapachy, wartości, cała pamięć serca, to co ulotne, co było, cała przeszłość z symbolami i przedmiotami, których już nie ma, obyczaje" ${ }^{3}$. Tak dokonana analiza prowadzi do sformułowania implikacji pedagogicznych, w których badacz (opierając się na poczynionych wcześniej interpretacjach) wskaże to, co wyjątkowe w doświadczeniu jednostki. Im głębiej badacz odkryje struktury i poziomy współistnienia poszczególnych elementów, tym głębsze będzie rozumienie zjawiska, a $w$ konsekwencji tym bardziej znacząca wiedza uzyskana na drodze interpretacji.

W implikacjach pedagogicznych badacz, korzystając z sieci związków między aktorami, miejscami, czasem, wartościami oraz oczekiwaniami i życzeniami odkrytymi w poprzednich etapach, dokonuje rekonstrukcji doświadczenia. Na podstawie dokonanej identyfikacji wzajemnych powiązań czynników kształtujących rzeczywistość próbuje zrozumieć skutki, jakie osoba uzyskuje w wyniku doświadczenia. Może również próbować określić, czy prowadzą one do korekty dotychczasowych postaw i zachowań, czy wprowadzają w życie osoby nową jakość. Pierwsze określane są mianem moderacji, a drugie mianem synergii ${ }^{4}$.

\section{Podsumowanie}

Refleksja nad narracjami prowadzona za pomocą analizy strukturalnej umożliwia identyfikację skutków doświadczenia poprzez ich twórcze i rozumiejące odkrywanie. Wskazywanie i interpretacja aktorów, miejsca, czasu, wartości oraz oczekiwań i życzeń prowadzi do sformułowania implikacji pedagogicznych, które opisują zaobserwowany i odkryty przebieg spraw; uwidaczniają pewne prawdy,

\footnotetext{
${ }^{1}$ O. Czerniawska, Przedmowa, [w:] Drogi edukacyjne i ich biograficzny wymiar, red. O. Czerniawska, E. Dubas, Instytut Technologii Eksploatacji, Warszawa - Radom 2002, s. 7.

${ }^{2}$ Tamże.

3 Tamże.

${ }^{4}$ A. Walulik, Moderacyjne i synergiczne kształtowanie dorosłości..., dz. cyt., s. 139.
} 
które zdaniem badanego i badacza można dostrzec podczas ludzkiego życia. Nie posiadają $w$ żadnej mierze charakteru instrukcji, czy uogólniających wniosków, ani nie pokazują jak „sprawy powinny przebiegać”. Pozwalają natomiast poznać różnorodność charakteryzującą obecność osoby w świecie oraz zrozumieć i docenić ludzi znajdujących się $w$ jej otoczeniu. Dochodzenie do tak rozumianych implikacji pedagogicznych pozwala uznać analizę strukturalną za technikę umożliwiającą systematyczną refleksję nad „danymi” zgromadzonymi sposobami typowymi dla badań jakościowych.

\section{Bibliografia}

Advances in Experimental Social Psychology, t. 21, red. L. Berkowitz, Academic Press, London 1988.

Analiza transakcyjna w edukacji, red. J. Jagieła, Wydawnictwo im. Stanisława Podobińskiego Akademii im. Jana Długosza, Częstochowa 2011.

Ankersmit F., Narracja, reprezentacja, doświadczenie. Studia z teorii historiografii, Universitas, Kraków 2004.

Aporie czasu, red. P. Orlik, Wydawnictwo Naukowe Instytutu Filozofii UAM, Poznań 2011.

Drogi edukacyjne i ich biograficzny wymiar, red. O. Czerniawska, E. Dubas,

Instytut Technologii Eksploatacji, Warszawa - Radom 2002.

Dyczewski L., Miejsce i funkcja wartości $w$ kulturze, „Keryks” 2008, nr 7.

Katechizacja różnymi metodami, red. M. Majewski, Inspektorat Towarzystwa Salezjańskiego, Kraków 1994.

Kochel J., Marek Z., Pedagogia biblijna w katechezie, Wydawnictwo WAM, Kraków 2012.

Kurantowicz E., Badanie lokalnych kontekstów uczenia się. Wybrane (andragogiczne) uzasadnienia i spory, „Teraźniejszość - Człowiek - Edukacja” $2006 \mathrm{nr} 2(34)$, s. 63-64.

Kurs Biblijny, z. 2, red. Z. Marek, Wydawnictwo WAM, Kraków 1993.

Łobocki M., Wychowanie moralne w zarysie, Oficyna Wydawnicza „Impuls”, Kraków 2002. 
Marek Z., Biblia w katechetycznej posłudze słowa, Wydawnictwo WAM, Kraków 1998.

Marek Z., O korzystaniu z Pisma Świętego w głoszeniu zbawczego orędzia, „Horyzonty Wiary” 1995, R. 6, nr 3.

Marek Z., Podstawy wychowania moralnego, Wyższa Szkoła FilozoficznoPedagogiczna „Ignatianum”, Wydawnictwo WAM, Kraków 2005.

Narracja jako sposób rozumienia świata, red. J. Trzebiński, Gdańskie Wydawnictwo Psychologiczne, Gdańsk 2002.

Narracja - teoria i praktyka, red. B. Janusz, K. Gdowska, B. de Barbaro, Wydawnictwo Uniwersytetu Jagiellońskiego, Kraków 2008.

Niparko R., Wychowanie religijne jako wychowanie humanistyczne - perspektywa personalistyczna, „Paedagogia Christiana” 2003, nr 2 (12).

Nowak M., Pedagogika personalistyczna, [w:] Pedagogika: podręcznik akademicki, t. 1, red. Z. Kwieciński, B. Śliwerski, Wydawnictwo Naukowe PWN, Warszawa 2003.

Pedagogika miejsca, red. M. Mendel, Wydawnictwo Naukowe DSWE TWP, Wrocław 2006.

Praktyczny słownik współczesnej polszczyzny, t. 25, 50, red. H. Zgółkowa, Wydawnictwo Kurpisz, Poznań 2000.

Walulik A., Moderacyjne i synergiczne kształtowanie dorosłości. Propozycja typologii modeli znaczeń wiedzy religijnej na przykładzie Korespondencyjnego Kursu Biblijnego, Wyższa Szkoła FilozoficznoPedagogiczna „Ignatianum”, Wydawnictwo WAM, Kraków 2011. Zatorski W., Kairos i Chronos $w$ życiu lidera, http://ps-po.pl//wp-content/uploads/2013/08/kairos_i_chronos_w_zyciu_lidera.pdf. 